major tour de force, the sequence of at least the interesting parts of the human genome by the year 2000. But it is beginning to look as if we shall have to wait a lot longer before we know how the whole thing works; perhaps project 3000 will tell us how a fertilized egg turns into a human being.

These thoughts are echoed in the foreword to these volumes, in which Watson predicts that the overwhelming information explosion in this field, rather than reflecting a short period of highly productive research in the human biological sciences, gives every indication of opening up new frontiers that will take hundreds if not thousands of years to explore thoroughly. It is slightly disturbing, therefore, that the symposium does not include any discussion of the broader social implications of the new genetics or any mention of the ethical questions that may arise as we come to dissect the human genome down to its last few molecular bricks. How, for example, will doctors cope with an increasingly reductive approach to the medical sciences when, at the same time, they are being urged to concentrate more on the holistic aspects of patient care? And how far do we wish to go in the social engineering that will follow inevitably from our increasing knowledge of the human genome? Surely it must have been the same in the physical sciences at the beginning of the century; things were moving so fast and so much excitement was being generated that there was no time to step back and evaluate the longterm implications of what was happening. But if the biologists are not to create problems of even greater magnitude than those that stemmed from the vintage years of physics, it will be important for us to reflect on these questions; given the current pace of development of human molecular biology, as evidenced by these splendid books, this will not be easy.

Sir David Weatherall is Nuffield Professor of Clinical Medicine and Honorary Director of the Medical Research Council Molecular Haematology Unit, University of Oxford, John Radcliffe Hospital, Oxford OX3 9DU, UK.

\section{Hardy perennial}

\author{
Clive Stace
}

Flora of the British Isles, 3rd Edn. By A.R. Clapham, T.G. Tutin and D.M. Moore. Cambridge University Press: 1987. Pp.688. £65, $\$ 125$.

Flora of the British Isles (or 'CTW' as it is almost invariably known) is the standard British and Irish flora, and the appearance of the third edition 35 and 25 years after the first and second editions, respectively, is a noteworthy event. The accounts prepared by E.F. Warburg, who died in 1966 , have been taken over and updated by D.M. Moore of Reading University.

Although the book looks quite different at a glance, with its glossy front and new text format in two columns, this third edition is clearly only an updated version of its predecessors, and in some respects only partially updated at that. Hence all the long-familiar features of CTW are still to be found and need not be described again here. Its strongest points are the reasonably detailed descriptions and the relatively copious peripheral data included on such points as ecology, pollination, phenology, dispersal and chromosome numbers. Mention of a large number of commonly grown related garden plants is also an often welcome additional feature. This flora is therefore of value to a wide range of biologists - in taxonomic terminology it is a general-purpose flora rather than a specialist's handbook.

Since the second edition of CTW (published in 1962), all five volumes of Flora Europaea (1964-1980) have appeared, and, as expected, many of the latter's taxonomic features are utilized in the latest edition of CTW. The preface states that national floras in Europe should adopt the taxonomy and nomenclature of Flora Europaea, "unless there seemed good grounds for doing otherwise". In fact there are quite frequent deviations (but the "good grounds" are not explained), for example Alcea/Althaea, Chamaenerion/Epilobium, Filago etc., Centaurea nigra agg., Salicornia species. The sequence of families is retained as in the earlier editions (except for the pteridophytes), but within the families the generic sequence has often been modified, frequently to agree with Flora Europaea.

To the specialist the greatest disappointments fall into three categories. There are many inconsistencies in the treatments, ranging from contradictions to stated policy (for example, names of counties and English names of plants used) to the very varied treatment of comparable groups (for example, three and ten columns, respectively, for the abundant Taraxacum and Rubus agamospecies, yet twenty-four for the much less common Hieracium; random use of terms 'agg.', 'group', and so on). Secondly, there are numerous examples of (mostly trivial) points that have not been adequately updated. Many names used have been shown to be incorrect according to the Code (such as Thlaspi alpestre, Oenothera erythrosepala, Festuca tenuifolia); distribution patterns are sometimes outdated (especially concerning aliens); results of some recent taxonomic research have not been incorporated. (Rumex tenuifolius, Carduus acanthoides, Rhynchosinapis, among others); and the figures have not been updated since the 1952 edition (Sorbus wilmottiana, for example, described even in the 1962 edition, has not been added). Thirdly, the coverage of alien plants is very often unsatisfactory. Many species that no longer occur (for example, Rosa sempervirens) or never did (for example, Phytolacca americana) are given extensive coverage, while others now common, such as Geranium $x$ magnificum, are not mentioned. Twenty lines are devoted to Salix elaeagnos, which is not naturalized in Britain, while $S$. cordata, well naturalized in Warwickshire, is not covered. Numerous similar examples exist.

Unfortunately, due to a serious clerical error, the family Zannichelliaceae has been completely omitted from the text and index, though it appears in the family keys and synopsis. After its point of omission (p.531) the families have been renumbered, so that from that point their numbers do not correspond with those in the synopsis and keys. The common grass called Festuca diffusa in Flora Europaea and $F$. rubra ssp. multiflora in C.E. Hubbard's Grasses (Penguin, 3rd edn, 1984) is omitted altogether, probably because Britain was erroneously not included in its distribution in Flora Europaea.

Production of the 1952 edition of CTW was a magnificent achievement that has not been equalled since. The latest edition is likely to remain the standard British flora well into the next century, but it is a pity that it has not quite kept pace with our increase in knowledge. The price, however, at 26 times that of the original, is fully updated.

Clive Stace is Professor of Plant Taxonomy in the University of Leicester, Leicester LE1 7RH, $U K$, and President of the Botanical Society of the British Isles.

\section{New in paperback}

- Light and Photosynthesis in Aquatic Ecosystems by John T. O. Kirk. Publisher is Cambridge University Press, price is $£ 15, \$ 24.95$. For review see Nature 309, 382 (1984).

- An Introduction to Science Studies: The Philosophical and Social Aspects of Science and Technology by John Ziman. Publisher is Cambridge University Press, price is $£ 9.95, \$ 14.95$. For review see Nature 314, 204 (1985).

- Intermolecular Forces: Their Origin and Determination by Geoffrey C. Maitland, Maurice Rigby, E. Brian Smith and William A. Wakeham. Publisher is Oxford University Press, price is $£ 20, \$ 37.50$. For review see Nature 294, 384 (1981).

\section{New in Britain}

- The Griffin by Arnold Kramish. Publisher is Macmillan, price is $£ 12.95$. For review see Nature 325, 203 (1987).

- Prescription For Disaster: From the Glory of Apollo to the Betrayal of the Shuttle by Joseph J. Trento. To be published on September 24 by Harrap, price $£ 12.95$. For review see Nature 327, 289 (1987). 